\title{
Alban Georges, Tristan de Nanteuil. Ecriture et imaginaire épiques au XIV siècle
}

\section{G. Matteo Roccati}

\section{(2) OpenEdition}

\section{Journals}

\section{Édition électronique}

URL : http://journals.openedition.org/studifrancesi/5841

DOI : 10.4000/studifrancesi.5841

ISSN : 2427-5856

\section{Éditeur}

Rosenberg \& Sellier

\section{Édition imprimée}

Date de publication : 1 mai 2011

Pagination : 141-142

ISSN : 0039-2944

\section{Référence électronique}

G. Matteo Roccati, «Alban Georges, Tristan de Nanteuil. Ecriture et imaginaire épiques au xiv siècle», Studi Francesi [En ligne], 163 (LV | I) | 2011, mis en ligne le 30 novembre 2015, consulté le 11 janvier 2021. URL : http://journals.openedition.org/studifrancesi/5841 ; DOI : https://doi.org/10.4000/ studifrancesi.5841

Ce document a été généré automatiquement le 11 janvier 2021.

\section{(c) (i) () $\Theta$}

Studi Francesi è distribuita con Licenza Creative Commons Attribuzione - Non commerciale - Non opere derivate 4.0 Internazionale. 


\title{
Alban Georges, Tristan de Nanteuil. Ecriture et imaginaire épiques au XIV siècle
}

\author{
G. Matteo Roccati
}

\section{RÉFÉRENCE}

ALBAN GEORGES, Tristan de Nanteuil. Ecriture et imaginaire épiques au XIV siècle, Paris, Honoré Champion éditeur, 2006 («Nouvelle bibliothèque du Moyen Age», 80), pp. 750.

1 L'ouvrage est une étude attentive et analytique de la chanson, étude soucieuse de repérer les caractéristiques de l'évolution du genre au XIV ${ }^{\mathrm{e}}$ siècle. Il s'articule en trois parties. Tout d'abord l'A. situe le Tristan à l'intérieur de la geste de Nanteuil, dont la constitution s'étale sur près de deux siècles, donne une analyse détaillée du poème (pp.71-105) et examine les structures spatiale et temporelle du texte, ainsi que son organisation narrative (notamment par le procédé de l'entrelacement). Il passe ensuite à l'étude de l'Ecriture épique (laisse, thèmes et motifs épiques, annonces et rappels), enfin à celle des contenus, organisée «autour des grandes figures littéraires, à la fois porteuses de stéréotypes et de symboles, [...] emblématiques de la richesse et de la complexité du poème» (pp. 439-440): l'initiation du héros épique, le travestissement, la transsexualité et la figure mythique de l'androgyne, le saint, les schémas œdipiens. Différents annexes et tableaux (Généalogie des personnages de la Geste de Nanteuil, pp. 66-67; La succession généalogique des protagonistes dans quelques chansons du XIV siècle, p. 175; Le voyage en Féerie dans quelques œuvres du XII ${ }^{e}$ au XIVe siècle, pp. 540-543; Sommaire des motifs narratifs, pp. 713-719) rassemblent utilement des données intéressantes. La bibliographie et l'index des auteurs et des œuvres terminent le volume. 